\title{
ANANCYLUS ROSANAE (GASTROPODA: PULMONATA), NEW GENUS AND NEW SPECIES, FROM IGUAZÚ NATIONAL PARK, ARGENTINA
}

\author{
Diego E. Gutiérrez Gregoric
}

\begin{abstract}
División Zoología Invertebrados, Museo de La Plata, Facultad de Ciencias Naturales y Museo, Universidad Nacional de La Plata, La Plata, Buenos Aires, Argentina; Consejo Nacional de Investigaciones Científicas y Técnicas (CONICET); dieguty@fcnym.unlp.edu.ar
\end{abstract}

\begin{abstract}
Seventeen species of ancylids occur in southern South America, seven in Argentina. Anancylus rosanae, n. gen. et sp., is described based on characters of the shell, radula, jaw and reproductive system. This new genus, found in the upper Iguazú River rapids, Iguazú National Park, Misiones Province, Argentina, has the following distinctive features: patelliform shell, usually low, with a circular apex located at the anterior end of the shell; three adductor muscles: large posterior (twice the length of the anterior muscles) and two tear-shaped anterior; adhesive epithelium between the two anterior muscular insertions; no difference between the plates of the jaw.
\end{abstract}

Key words: Anancylus rosanae, n. gen. et sp., Ancylidae, shell, anatomy, Argentina.

\section{INTRODUCTION}

American patelliform freshwater gastropods have been included within Ancylidae, Acroloxidae and Lymnaeidae. Only the Ancylidae are present in South America. In southern South America (Brazil, Argentina, Uruguay, Paraguay and Chile), this family is represented by $A n$ isancylus Pilsbry, 1924 (2 species), Burnupia Walker, 1912 (1 species), Ferrisia Walker, 1903 (1 species), Gundlachia Pfeiffer, 1849 (6 species), Hebetancylus Pilsbry, 1913 (2 species), Laevapex Walker, 1903 (1 species) and Uncancylus Pilsbry, 1913 (4 species) (Lanzer, 1996; Santos, 2003; Simone, 2006). The following species have been recorded in Argentina: Uncancylus concentricus (d'Orbigny, 1835), Hebetancylus moricandi (d'Orbigny, 1837), Anisancylus obliquus (Broderip \& Sowerby, 1832), Gundlachia ticaga (Marcus \& Marcus, 1962) and G. radiata (Guilding, 1828) (Fernández, 1981; Rumi et al., 2006, 2008; Ovando et al., 2011). Of the species found in Argentina, the first two have a widespread distribution, whereas $A$. obliquus has only been recorded in the south and centre, and the other two species - G. ticaga and G. radiata - have been recorded only in the provinces of Misiones and Jujuy, respectively (Gutiérrez Gregoric et al., 2006; Rumi et al., 2006, 2008; Ovando et al., 2011). Recently, Ferrisia was reported from northwest Argentina and Laevapex was cited from the northeast (Iguazú River) (Gutiérrez Gregoric et al., 2006; Rumi et al., 2006, 2008; Agudo, 2007; Ovando \& Santos, 2011).

The taxonomic placement of the Ancylidae has changed over the years. This freshwater limpet clade has been recognized at the family level as the Ancylidae (Boss, 1982; Brown, 1994; Santos, 2003; Albrecht et al., 2004; Simone, 2006; Walther, 2008; Ovando et al., 2011); alternatively, it has been placed within the larger family Ancyloplanorbidae (= Planorboidea) (Hubendick, 1978); and it has also appeared as a subfamily or a tribe of Planorbidae (Burch, 1962; Starobogatov, 1967; Bouchet \& Rocroi, 2005; Albrecht et al., 2006, 2007; Walther et al., 2010). Albrecht et al. (2004), based on molecular studies, included various genera in the Ancylidae, but separated the genus Burnupia from the group. Later, Albrecht et al. $(2006,2007)$ proposed a new family (unnamed) for Burnupia. In the absence of a definite position, I will consider the genera previously mentioned of patelliform freshwater gastropods of Argentina as Ancylidae.

In this study, the material from the Iguazú River, Misiones Province, Argentina, previously identified as Laevapex sp., was revised based on the shell and soft-body parts, and a new genus and new species, Anancylus rosanae, were generated. 


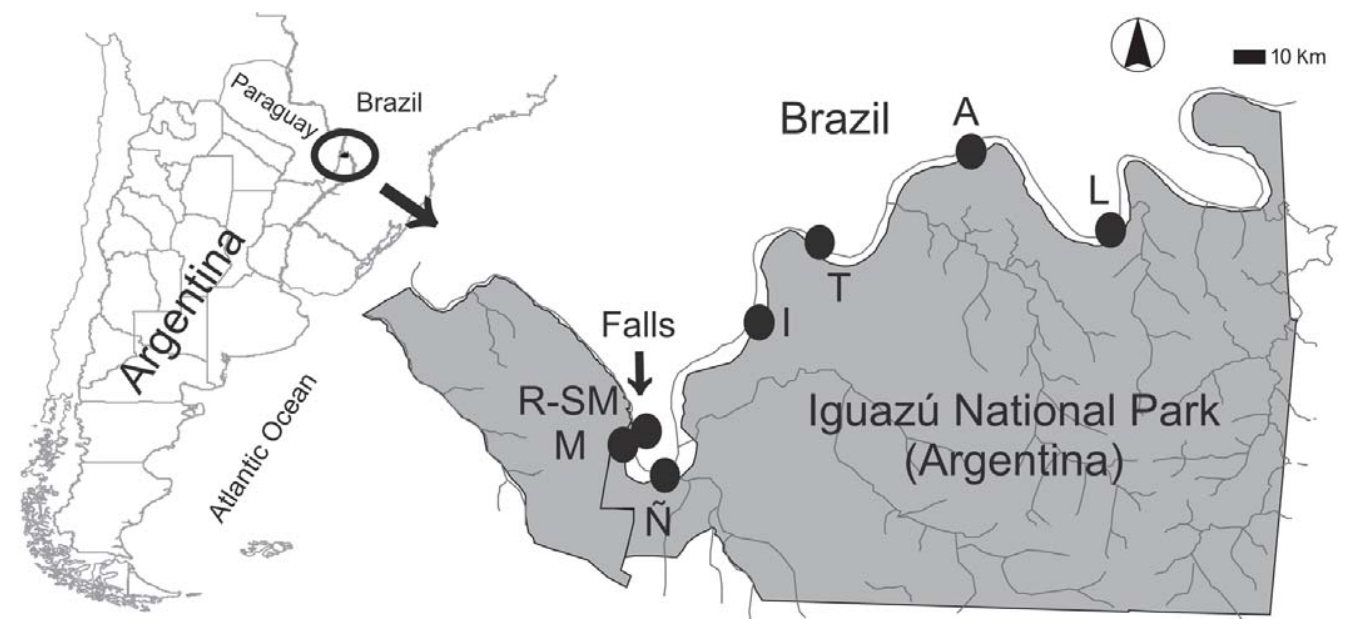

FIG. 1. Rapids of the Iguazú River where Anancylus rosanae was recorded, Iguazú National Park, Argentina. A: Apepú; I: Irene; L: León; M: Mbigua; Ñ: Ñandú; R - SM: Rivadavia and San Martín; T: Tacuara.

\section{MATERIALS AND METHODS}

Specimens were collected in 2004 and 2005 in Iguazú National Park, Misiones Province, Argentina (Fig. 1, Table 1). Soft parts were separated from the shell after relaxation in $10 \%$ Nembutal solution for $4 \mathrm{~h}$ and then fixed in modified Raillet-Henry solution for freshwater animals $(93 \%$ distilled water, $2 \%$ glacial acetic acid, $5 \%$ formaldehyde and $6 \mathrm{~g} / \mathrm{l}$ sodium chloride solution). Radulae and jaws were separated from the buccal mass and then cleaned with sodium hypochlorite (Clorox).
Five shell measurements were taken: total length (TL), anterior width (at apex) (AW), total width (TW), height $(\mathrm{H})$ and diameter of apex (DA) (Fig. 2). Radulae $(n=3)$ and jaws $(n=$ 2) were observed under a scanning electron microscope JEOL 6360 at the Museo de La Plata (Facultad de Ciencias Naturales y Museo - Universidad Nacional de La Plata). Internal anatomy $(n=8)$ was analyzed using a Leica MZ6 stereoscopic binocular microscope with camera lucida. For the anatomical studies, the methodology proposed by Santos (2003) was followed.

TABLE 1. Number of specimens collected during different months at each rapids where Anancylus rosanae was recorded, Iguazú National Park, Argentina.

\begin{tabular}{lcccccccc}
\hline & Nandú & San Martín & Tacuara & Mbigua & León & Apepú & Irene & Rivadavia \\
\hline South & $25^{\circ} 42^{\prime}$ & $25^{\circ} 41^{\prime}$ & $25^{\circ} 36^{\prime}$ & $25^{\circ} 41^{\prime}$ & $25^{\circ} 36^{\prime}$ & $25^{\circ} 33^{\prime}$ & $25^{\circ} 38^{\prime}$ & $25^{\circ} 41^{\prime}$ \\
West & $54^{\circ} 25^{\prime}$ & $54^{\circ} 27^{\prime}$ & $54^{\circ} 21^{\prime}$ & $54^{\circ} 26^{\prime}$ & $54^{\circ} 14^{\prime}$ & $54^{\circ} 17^{\prime}$ & $54^{\circ} 23^{\prime}$ & $54^{\circ} 26^{\prime}$ \\
Feb-04 & 25 & & & & & & & 7 \\
Jun-04 & & & 13 & & & & & \\
Feb-05 & & & 25 & & 30 & 20 & 3 & \\
Jun-05 & & 5 & & 8 & & & & \\
Dec-05 & 8 & & & & & & & \\
\hline
\end{tabular}




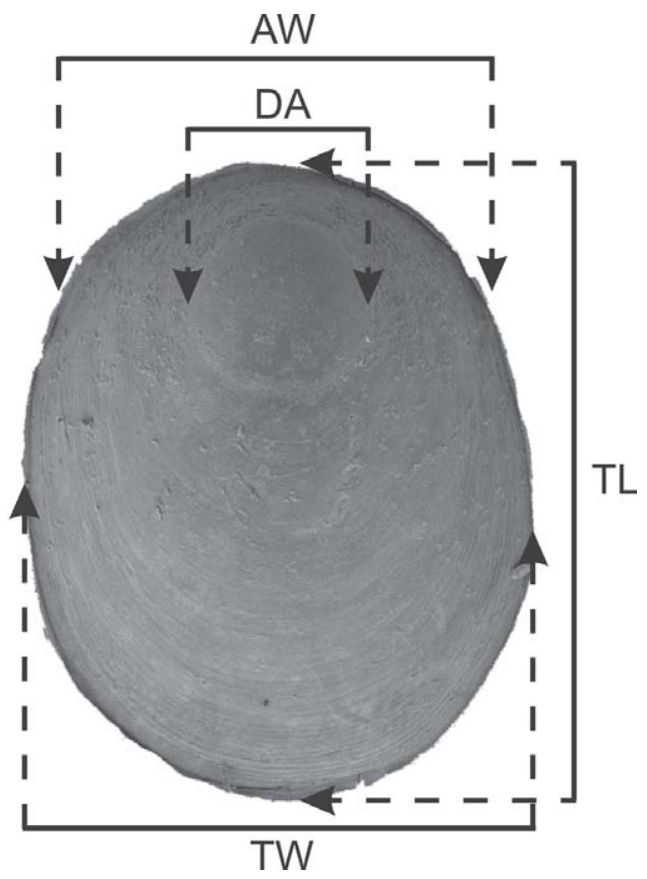

FIG. 2. Shell measurements used for Anancylus rosanae, n. sp.: TL: Total length; AW: Anterior width; TW: Total width; DA: Diameter of apex.

\section{RESULTS}

\section{Anancylus gen. nov.}

Type Species

Anancylus rosanae, sp. nov.; Argentina.

\section{Diagnosis}

Shell patelliform, usually low, circular apex located along midline at anterior end of shell. Three adductor muscles present: large posterior (twice length of anterior muscles) and two tear-shaped anterior muscles. Adhesive epithelium between two anterior muscles. Radula with more than one hundred rows of teeth. Central tooth asymmetric, tricuspid. First lateral tooth tricuspid, tall endocone. Jaw plates low and wide, undifferentiated. Free edge of plates denticulate. Genital system: tubular ovotestis, thick flagellum (three times longer than prepucium), tubular prolongation of uterus three times longer than ovotestis.

\section{Etymology}

$A n=$ without ; ancylus = because of the hooked curved shape.

Differentiation

See Discussion below.

Anancylus rosanae sp. nov.

(Figs. 2-18)

Laevapex sp.; Gutiérrez Gregoric et al., 2006: 51-60; Rumi et al., 2006: 199, 207; Agudo, 2007: 6; Rumi et al., 2008: 83, 102.

Type Locality

Upper Iguazú River, Iguazú National Park, Misiones Province, Argentina.

Type Material

Holotype (MLP: 13219); and paratypes (MLP: 13220, 7 specimens) housed at Museo de La Plata.

\section{Etymology}

Dedicated to Rosane Lanzer.

\section{Description}

Shell (Figs. 2-7): Shell patelliform, small, low. Aperture elliptic, edge smooth. Anterior end narrower than posterior end. Periostracum hyaline (transparent), slightly yellow, fine concentric growth lines; no radial lines. Apex smooth, rounded, located along midline at anterior end of shell.

Measurements (in $\mathrm{mm}$ ): TL: average $2.25(\mathrm{~N}$ : 38; Range: 0.92 - 3.07; SD: 0.40); TW: average 1.74 (N: 38; Range: $0.77-2.42$; SD: 0.33); AW: average 1.55 (N: 38; Range: $0.72-2.07$; SD: 0.30 ); $\mathrm{H}$ : average 0.56 (N: 30; Range: $0.32-$ 0.77 ; SD: 0.10 ); DA: 0.73 (N: 33; Range: 0.47 1.12; SD: 0.21). Table 2 shows measurements for the holotype and paratypes.

Body (Figs. 6, 8, 9): Tentacles cylindrical, not pigmented. Pigmentation of mantle concentrated in the center. Edges with radial bands diffusely pigmented. Three well-developed adductor muscles observed: two anterior and one posterior. Two anterior muscles tear-shaped, 

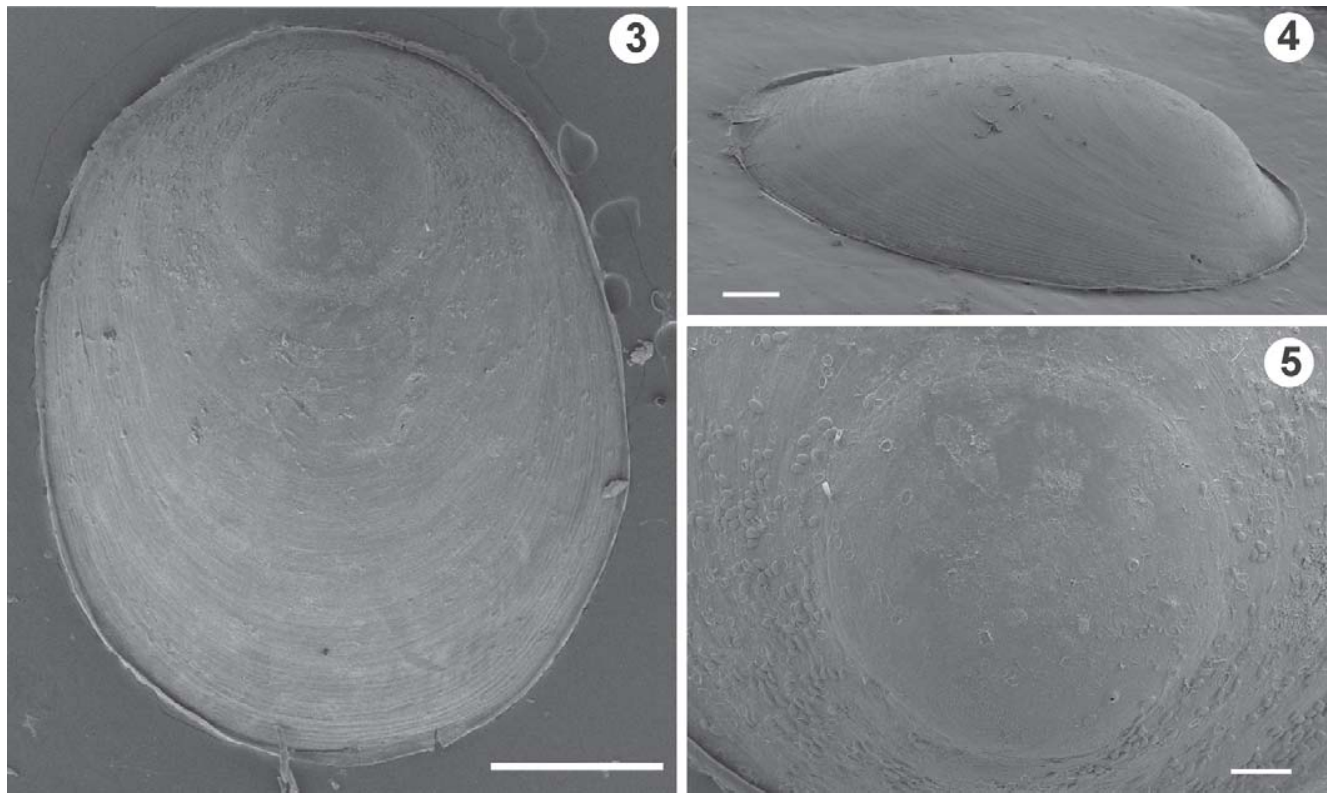

FIGS. 3-5. Shells of Anancylus rosanae, n. sp. FIG. 3: Dorsal view; FIG. 4: Lateral view; FIG. 5: Apex. Scale bars: FIG. $3=0.5 \mathrm{~mm}$; FIG. $4=0.2 \mathrm{~mm}$; FIG. $5=0.1 \mathrm{~mm}$.

connected by adhesive epithelium (Fig. 8). Large posterior muscle (twice the length of anterior muscles), spans the full width of the visceral mass $(46.6 \%$ of total shell width). Pseudobranch single-lobed, located behind female pore.

Digestive System: The digestive system has no features of special interest. Radular sac proj- ects beyond pharyngeal bulb into the visceral mass. Long intestine (two times the total body length), curved at the back, opens behind the pseudobranch.

Jaw (Figs. 10-13): Jaw horseshoe-shaped with 44 plates, all similar except for size. Plates rectangular, wider than tall. Free edge of plates with chitinous projections (Figs. 12, 13).
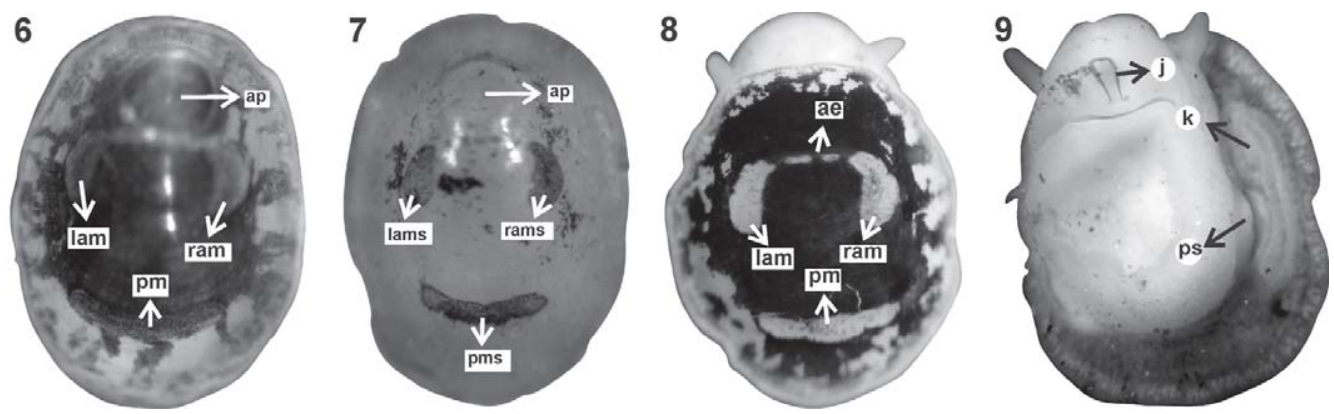

FIGS. 6-9. Shell and mantle of Anancylus rosanae, n. sp. FIG. 6: Translucent shell through which the mantle is observed; FIG. 7: Shell; FIG. 8: Mantle; FIG. 9: Ventral view of body. Abbreviations: ae: adhesive epithelium; ap: apex; j: jaw; k: kidney; lam: left anterior muscle; lams: left anterior muscle scar; pm: posterior muscle; pms: posterior muscle scar; ps: pseudobranch; ram: right anterior muscle; rams: right anterior muscle scar. 
TABLE 2. Shell measurements ( $\mathrm{mm}$ ) of Anancylus rosanae (Holotype and Paratypes). TL: total length; AW: anterior width; TW: total width; H: height; DA: diameter of apex.

\begin{tabular}{lcccccc}
\hline \multicolumn{1}{c}{ Site } & Date & TL & TW & AW & H & DA \\
\hline Ñandú rapids (Holotype MLP 13219) & Dec-05 & 3.08 & 2.43 & 2.08 & 0.75 & 0.68 \\
Ñandú rapids (Paratype MLP 13220) & Dec-05 & 2.25 & 1.88 & 1.63 & 0.55 & 0.60 \\
Ñandú rapids (Paratype MLP 13220) & Dec-05 & 2.43 & 1.73 & 1.33 & 0.73 & 0.60 \\
Ñandú rapids (Paratype MLP 13220) & Dec-05 & 2.50 & 1.90 & 1.70 & 0.65 & 0.60 \\
Ñandú rapids (Paratype MLP 13220) & Dec-05 & 2.65 & 2.05 & 1.80 & 0.63 & 0.65 \\
Ñandú rapids (Paratype MLP 13220) & Dec-05 & 2.70 & 2.05 & 1.78 & 0.68 & 0.58 \\
Ñandú rapids (Paratype MLP 13220) & Dec-05 & 2.73 & 2.20 & 2.03 & 0.55 & 0.65 \\
Ñandú rapids (Paratype MLP 13220) & Dec-05 & 2.25 & 1.73 & 1.40 & 0.65 & 0.55 \\
\hline
\end{tabular}

Radula (Figs. 14-17): Between 105 and 145 rows of teeth per radula $(\mathrm{N}=3)$. Central tooth asymmetric, tricuspid, left cusp most developed. The base of the tooth - as well as the tooth itself - thin and uniform. First lateral tooth tricuspid, with endocone more developed. In some teeth, a subcusp can be seen outside the ectocone. Base and body tooth thin. From tooth 18 on, subcuspids appear toward the inner side of endocone: one in teeth 18 and 19, two in teeth 20 and 21 , and three between teeth 22 and the 23 . After tooth 18 , there is a reduction
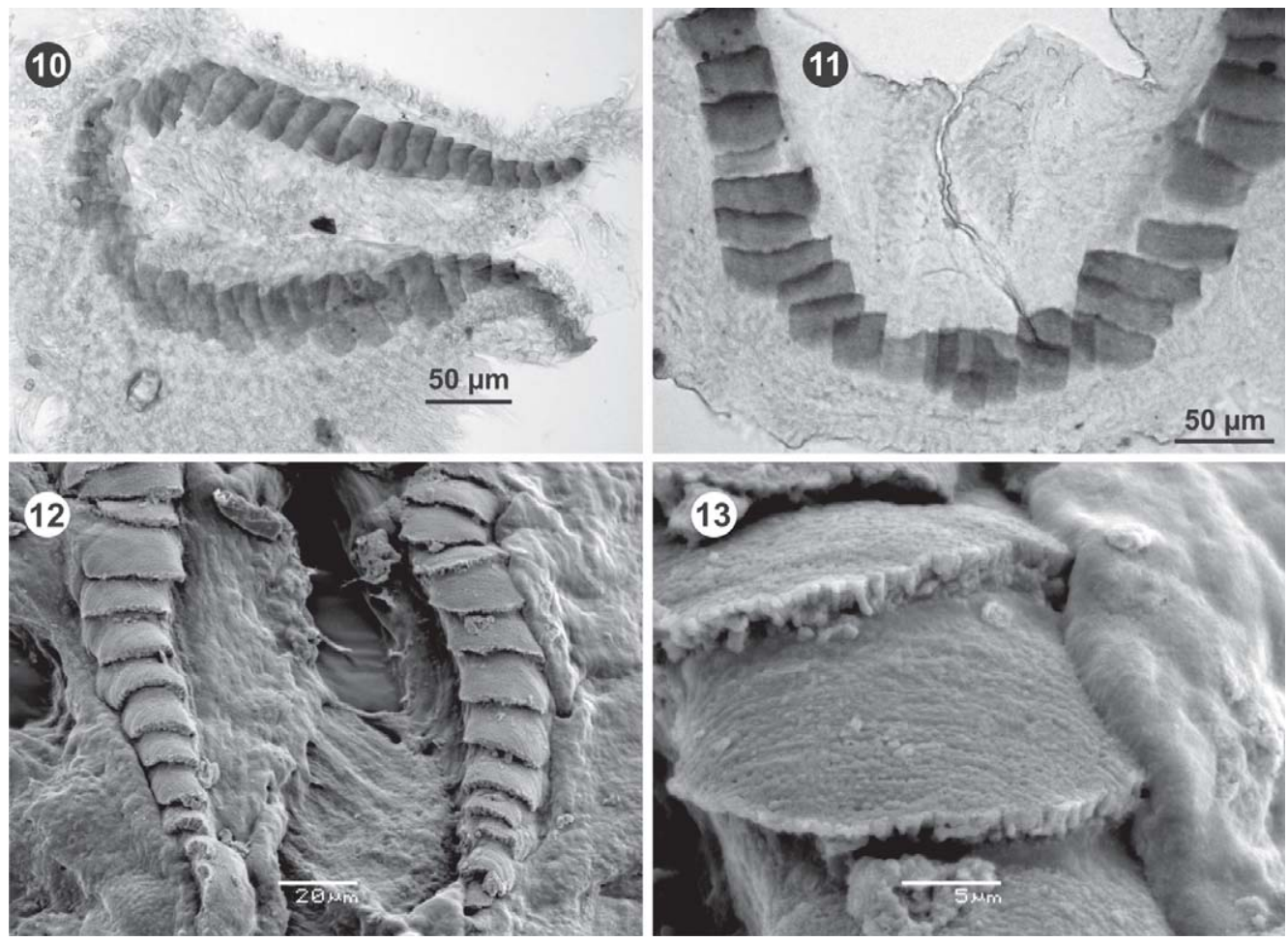

FIGS. 10-13. Jaw of Anancylus rosanae n. sp. FIGS. 10, 11: General view and plates in optic microscope view; FIGS. 12, 13: Plates in scanning electron microscope view. 
in tooth-size, ectocone and mesocone. The last teeth of the row (marginals) have seven cusps. The base of the tooth and its body widen from the central tooth towards the marginal teeth. Radular formula: $25( \pm 2)-1-25( \pm 2)$.

Reproductive System (Fig. 18): Ovotestis tubular, embedded in the digestive gland. From the ovotestis emerges the hermaphroditic duct, which coils up to become the seminal vesicle and then continues up to the carrefour. Female and male reproductive elements are described separately.

Female Genital System: Uterus surrounded by nidamental and albumen glands (the former cannot be seen in Fig. 18). Large tubular prolongation of the uterus (three times the length of ovotestis). Small vagina that opens in front of the pseudobranch. Spermathecal duct begins near the female genital pore; duct tubular and of the same size as ovotestis.
Male Genital System: Prostate emerging from the carrefour; tubular, smooth and thick. Vas deferens emerges from the prostate, crosses over the prepuce, and inserts at its proximal end. Flagellum large and thick (twice as thick as the vas deferens). Flagellum three times longer than prepucium. Male pore behind the left tentacle. Penis missing.

\section{Distribution}

The new species was found only at the type locality, that is, the rapids of the upper Iguazú River, Iguazú National Park (Table 1).

\section{DISCUSSION}

Previous identifications of Anancylus rosanae as Laevapex sp. for the upper Iguazú River (Gutiérrez Gregoric et al., 2006; Rumi et al., 2006, 2008; Agudo, 2007) may be explained by
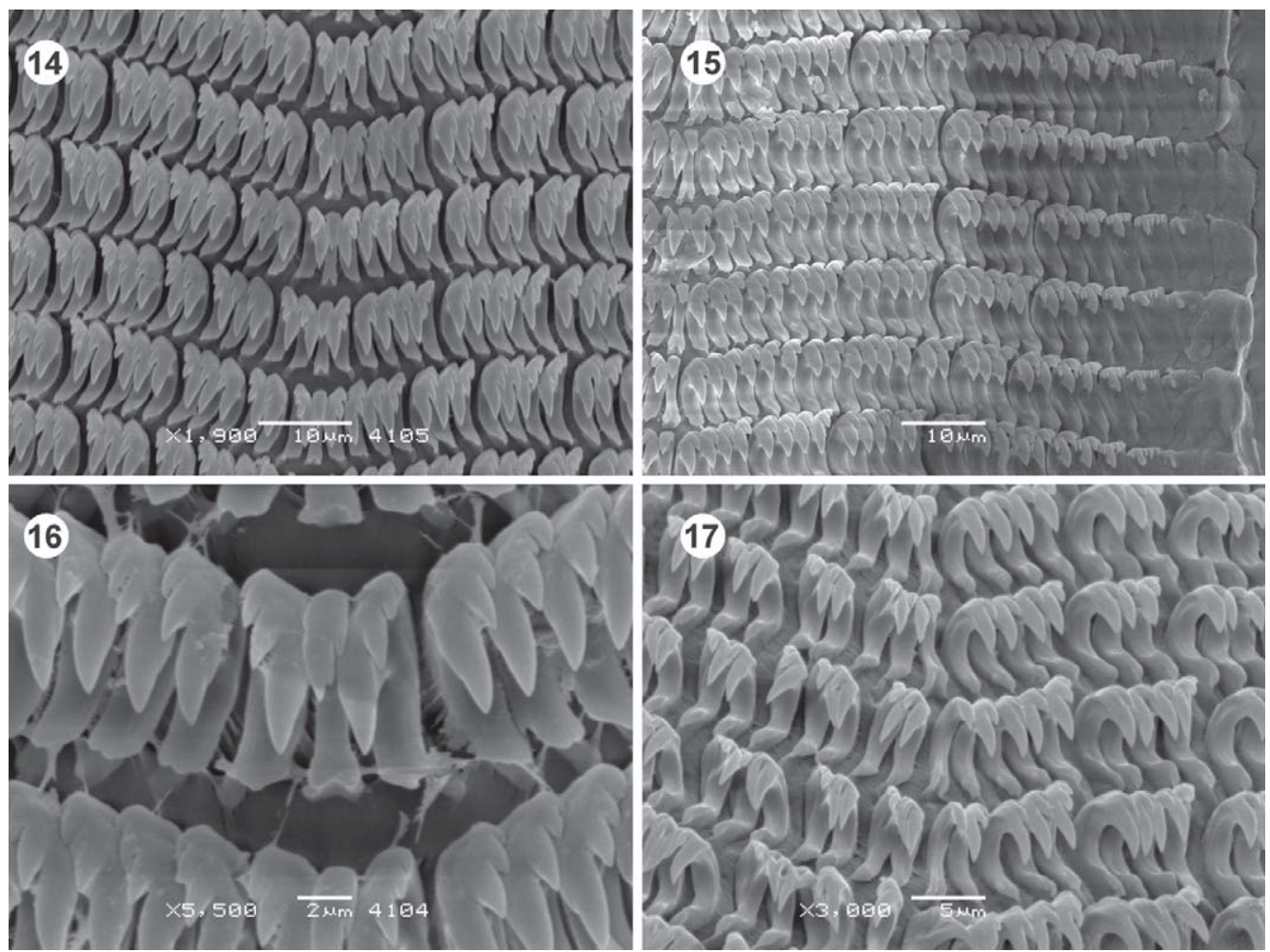

FIGS. 14-17. Radula of Anancylus rosanae, n. sp. FIGS. 14, 15: General view; FIG. 16: Central tooth and first lateral teeth; FIG. 17: Posterior-dorsal view. 


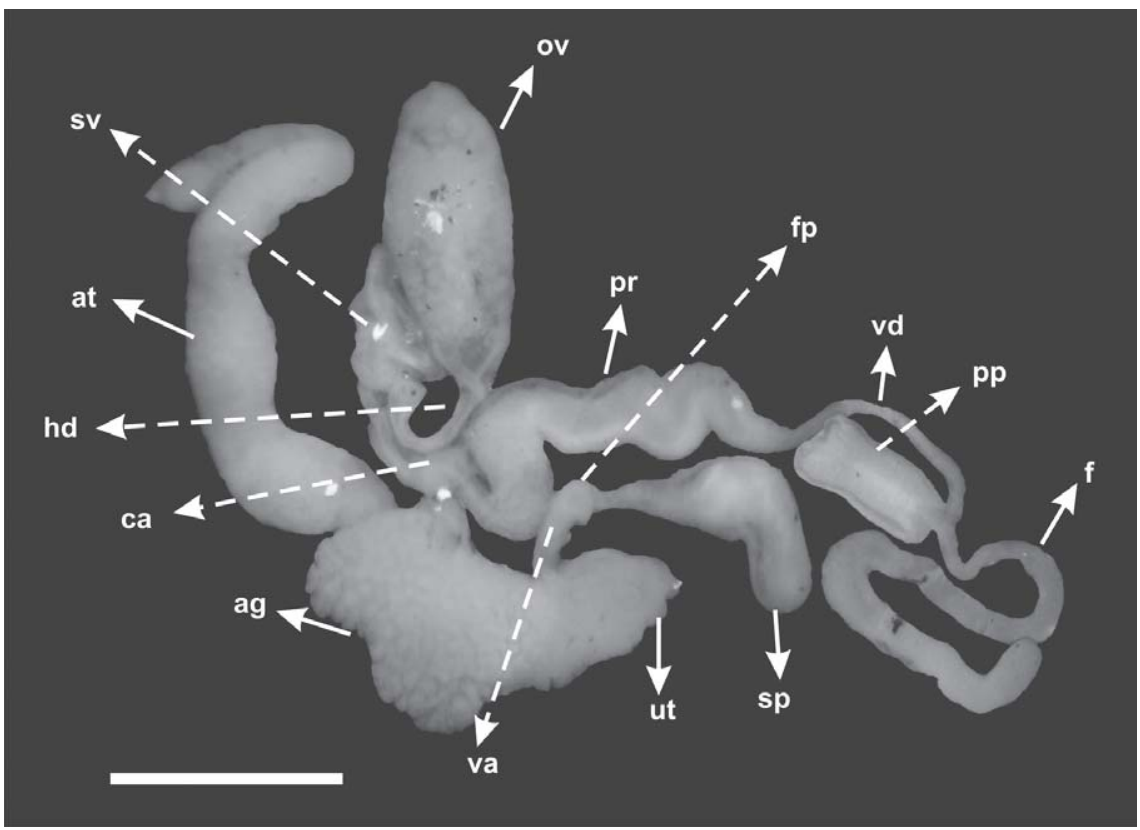

FIG. 18. Reproductive system of Anancylus rosanae, n. sp. Abbreviations: ag: albumen gland; at: tubular prolongation of uterus; ca: carrefour; vd: vas deferens; f: flagellum; fp: female pore; hd: hermaphrodite duct; ov: ovotestis; pp: prepuce; pr: prostate; sp: spermatheca; sv: seminal vesicle; ut: uterus; va: vagina. Scale bar: $0.5 \mathrm{~mm}$.

the fact that its descriptive characters agreed with those published by Lanzer (1996) for Laevapex. Lanzer (1996) did not accompany the description with shell figures or anatomical characters. She mentioned that the apex of the shell is obtuse, smooth and posterior. In the species described herein, the apex is smooth and obtuse, but it is located along midline at the anterior end of the shell. Placement of this new species in Laevapex is not appropriate, because in this genus the apex is obtuse, just behind the middle of the shell and inclined to the right. Rumi et al. $(2006,2008)$ and Agudo (2007) took the information mentioned in Gutiérrez Gregoric et al. (2006) repeating the error with regard to placement of the apex. The anterior placement of the shell apex distinguishes Anancylus from other ancylids, which until now were all described as having a central or posteriorly positioned apex.

Burch (1962) believed that the arrangement of adductor muscles is important in ancylid systematics. He recognized three subfamilies: Ancylinae, in which the adductor muscle is continuous and with a "C" shape; Laevapecinae has three small adductor muscles and adhesive epithelium between the posterior and right anterior muscles; Ferrissinae with three small muscles and no adhesive epithelium. The muscle arrangement of Anancylus rosanae does not resemble that of any of these three subfamilies. It has two anterior tear-shaped muscles curved along their posterior side and connected by an adhesive epithelium; the posterior muscle is longer and not connected by adhesive epithelium with the anterior muscles. Anancylus rosanae shows a muscle arrangement and pigmentation of the mantle that is similar to that described by Lanzer (1996) for Laevapex sp. from southern Brazil. However, as it was mentioned, the location of the collected specimens in the Iguazú River, identified as Laevapex sp., was erroneous.

In Anancylus rosanae, the base and body of the radula's central tooth are thinner than in other members of the family Ancylidae ( $A n-$ isancylus obliquus, Anisancylus dutrae Santos, 1994, Laevapex vazi Santos, 1989, Uncancylus concentricus), although the general pattern is similar. Anisancylus obliquus, A. dutrae, Gundlachia radiata (Bourguignat, 1853), Gundlachia ticaga, U. concentricus and Hebetancylus 
moricandi show a greater development of the mesocone in the first lateral teeth (Lanzer \& Veitenheimer-Mendes, 1985; Ohlweiler \& Lanzer, 1993; Santos, 1994, 2003), whereas in Anancylus rosanae the most developed cusp is the endocone. The species described herein has endocones in the marginal teeth, while all cusps are well developed in $A$. obliquus and, conversely, they are very poorly developed in $U$. concentricus.

The dorsal and lateral plates of the jaw of Anancylus rosanae reveal no differences between them (only a small difference in size) as can also be observed in Ferrissia rivularis (Say, 1817) (Hubendick, 1964). However, the new species has low and wide plates compared to the large, tall plates of $F$. rivularis. In other species of Ancylidae (A. obliquus, A. dutrae, and $L$. vazi), there is an obvious difference in size between dorsal and lateral plates. The free edge of the plates presents chitinous projections, a character not recorded in other species of Ancylidae (Santos, 1989, 1994; Ohlweiler \& Lanzer, 1993).

The reproductive system of Anancylus rosanae comprises a tubular ovotestis that differentiates it from other Ancylidae that have a hemispheric ovotestis (Santos, 2003). The prostate of Anancylus rosanae is tubular and smooth, while in Gundlachia, Uncancylus, Anisancylus and Hebetancylus the prostate has protuberances and follicles (Santos, 2003). The flagellum is large and thick, as it is in $A$. dutrae (Santos, 1994), and it is better developed than in Ferrissia and Gundlachia. A long, tubular prolongation of the uterus can be seen in the female reproductive system, while in $A$. obliquus, $A$. dutrae, $U$. concentricus and $H$. moricandi the prolongation is short and in some cases it is wider (Santos, 1994, 2000; Ohweiler \& Veitenheimer, 1995). Tubular prolongations of the uterus have not been mentioned in other species living in South America, such as Laevapex vazi, Ferrissia gentilis Lanzer, 1991, and Burnupia ingae Lanzer, 1991 (Santos, 1989; Lanzer, 1991). The poor development of the pseudobranch may be caused by the rapid and oxygenated water in which this species lives.

Anancylus differs from other members of the Ancylidae mainly in possessing an anterior apex and tubular ovotestis; however, it shares with the members of this family the general arrangement of the adductor muscles and the reproductive system in general. For this reason, Anancylus is provisionally placed in this family until such a placement is confirmed or rejected by molecular studies.

\section{ACKNOWLEDGEMENTS}

This study was financially supported by Consejo Nacional de Investigaciones Científicas y Técnicas (CONICET) (PIP 2711), Agency of Scientific Promotion (BID-PICT-2008-0233 and 2008-2042) and Facultad de Ciencias Naturales y Museo, Universidad Nacional de La Plata (PN636). The author wishes to thank the staff at the Centro de Investigaciones Ecológicas Subtropicales (CIES), Iguazú National Park, and V. Núñez and A. Rumi for support during field work. Comments by reviewers are also gratefully acknowledged.

\section{LITERATURE CITED}

AGUDO, A. I., 2007, Preliminary report of continental mollusks in the Central Paraná State Region, southern Brazil, with additional information. Ellipsaria, 9(2): 5-7.

ALBRECHT, C., K. KUHN \& B. STREIT, 2007, A molecular phylogeny of Planorboidea (Gastropoda, Pulmonata): insights from enhanced taxon sampling. Zoologica Scripta, 36: 27-39.

ALBRECHT, C., S. TRAJANOVSKI, K. KUHN, B. STREIT \& T. WILKE, 2006, Rapid evolution of an ancient lake species flock: Freshwater limpets (Gastropoda: Ancylidae) in the Balkan Lake Ohrid. Organisms, Diversity \& Evolution, 6: 294-307.

ALBRECHT, C., T. WILKE, K. KUHN \& B. STREIT, 2004, Convergent evolution of shell shape in freshwater limpets: the African genus Burnupia. Zoological Journal of the Linnean Society, 140: 577-586.

BOSS, K. J., 1982, Mollusca. Pp. 945-1166, in: S. P. PARKER, ed., Synopsis and classification of living organisms. McGraw Hill, New York, xviii + 1166 pp., pls. 1-87; 2: 1232 pp., pls. 88-141.

BOUCHET, P. \& J. P. ROCROIT, 2005, Classification and nomenclature of gastropod families. Malacologia, 47: 1-397.

BROWN, D. S., 1994, Freshwater snails of Africa and their medical importance. $2^{\text {nd }}$ ed. Taylor \& Francis, London, $x+608$ pp.

BURCH, J. B., 1962, Notes on the classification of freshwater limpets. Annual Report of the American Malacological Union, 8-9.

BURCH, J. B., 1982, North American freshwater snails: identification keys, generic synonymy, supplemental notes, glossary, references, index. Walkerana, 4: 1-365.

FERNÁNDEZ, D., 1981, Mollusca Gasterópoda: Ancylidae. Fauna de Agua Dulce de la República Argentina, PROFADU (CONICET), Buenos Aires, 15(7): 101-114.

GUTIÉRREZ GREGORIC, D. E., V. NUÑEZ, A. RUMI \& M. A. ROCHE, 2006, Freshwater Gastropods from Argentinean Del Plata basin. Checklist and new locality records. Comunicaciones de la Sociedad Malacológica del Uruguay, 9(89): 51-60. 
HUBENDICK, B., 1964, Studies on Ancylidae. The subgroups. Göteborgs Kungl Vetenskap-Och Vitterhets-Samhalles, 9B(6): 1-72.

HUBENDICK, B., 1978, Systematics and comparative morphology of the Basommatophora. Pp. 1-47, in: V. Fretter \& J. Peake, eds., Pulmonates, Vol. 2A, Systematics, Evolution and Ecology. Academic Press, London, xi + 540 pp.

LANZER, R., 1996, Ancylidae (Gastropoda, Basommatophora) na America do Sul: sistematica e distribuçao America del Sur. Revista Brasileira de Zoologia, 13: 175-210.

LANZER, R. \& I. L. VEITENHEIMER-MENDES 1985, Aspectors morfológicos e biológicos de uma populaçao de Gundlachia concentrica (Orbigny, 1835) (Mollusca, Ancylidae) de uma açude do sul do Brasil. Iheringia, Serie Zoologia, 65: 41-56.

OHLWEILER, F. P. \& R. M. LANZER, 1993, Morfologia da concha, rádula e mandíbula de Gundlachia obliqua (Broderip \& Sowerby, 1832) como una contribuçao a sistemática de Ancylidae (Mollusca; Basommatophora). Biociencias, 1(1): 121-149.

OHLWEILER, F. P. \& I. L. VEITENHEIMERMENDES, 1995, Sistema reproductor de Gundlachia concentrica (Orbigny) e Gundlachia moricandi (Orbigny), como subsidio para a taxonimia de Ancylidae (Mollusca, Gastropoda Pulmonata). Revista Brasileira de Zoologia, 12(3): 575-578.

OVANDO, X. M. C., L. E. M. LACERDA \& S. B SANTOS, 2011, Mollusca, Gastropoda, Heterobranchia, Ancylidae, Gundlachia radiata (Guilding, 1828): First record of occurrence for the Nothwestern region of Argentina. Chek list, 7(3): 263-266.

OVANDO, X. M. C. \& S. B. SANTOS, 2011, Ancylidae en el noroeste argentino: revisión sistemática y distribución. VIII Congreso Latinoamericano de Malacología, Puerto Madryn - Argentina. Resumenes: 226.

RUMI, A., D. E. GUTIÉRREZ GREGORIC, V. NÚÑEZ, I. I. CESAR, M. A. ROCHE, M. P. TASSARA, S. M. MARTÍN \& M. F. LÓPEZ ARMENGOL, 2006, Freshwater Gastropoda from Argentina: species richness, distribution patterns, and an evaluation of endangered species. Malacologia, 49: 189-208.

RUMI, A., D. E. GUTIÉRREZ GREGORIC, V. NÚÑEZ \& G. A. DARRIGRAN, 2008, Malacología latinoamericana. Moluscos de agua dulce de la República Argentina. Revista Biología Tropical, 56(1): 77-111.

SANTOS, S. B., 1989, On the morphology of Laevapex vazi n. sp. from Brazil (Mollusca: Pulmonata: Basommatophora: Ancylidae). Memorias do Instituto Oswaldo Cruz, 84(Suppl. 4): 467-473.

SANTOS, S. B., 1994, Gundlachia dutrae: n. sp. from northwest Brazil (Mollusca: Basommatophora: Ancylidae). Memorias do Instituto Oswaldo Cruz, 89(2): 153-160.

SANTOS, S. B., 2000, Morfologia do sistema muscular e do sistema reproductor de Anisancylus obliquus (Broderip \& Sowerby) do Chile, como contribucao a sistematica de Ancylidae (gastropoda, Pulmonata, Basommatophora). Revista Brasileira de Zoologia, 17(4): 995-1006.

SANTOS, S. B., 2003, Estado atual do conhecimento dos ancilídeos na América do Sul (Mollusca: Gastropoda: Pulmonata: Basommatophora). Revista de Biología Tropical, 51(Suppl. 3): 191-224.

SIMONE, L. R. L., 2006, Land and freshwater molluscs of Brazil. EGB, Fapesp., Sao Paulo, $390 \mathrm{pp}$.

STAROBOGATOV, Y. I., 1967, On the systematization of freshwater pulmonate molluscs. Trudy Zoologicheskogo Instituta Akademia Nauk SSSR, 42: 280-304.

WALTHER, A. C., 2008, A systematic study of North American freshwater limpets (Gastropoda: Hygrophila: Ancylidae). PhD Filosofical, University of Michigan, $124 \mathrm{pp}$.

WALTHER, A. C., J. B. BURCH \& O. F. DIARMAID, 2010, Molecular phylogenetic revision of the freshwater limpet genus Ferrisia (Planorbidae, Ancylinae) in North America yields two species: Ferrisia (Ferrisia) rivularis and Ferrisia (Kincaidilla) fragilis. Malacologia, 53: 25-46.

Revised ms. accepted 15 December 2011 